\title{
Assess the Effect of Integrated Nutrient Management on Vegetative Growth and Quality of Aonla cv. Francis
}

\author{
Sneha Singh ${ }^{1}$, Bhanu Pratap ${ }^{1}$, Vimlesh Kumar ${ }^{1}$, Govind Vishwakarma ${ }^{1}$, \\ Atul Yadav ${ }^{1 *}$, Dheeraj Yadav ${ }^{1}$ and Abhinav Kumar ${ }^{1}$
}

${ }^{1}$ Department of Horticulture, ${ }^{2}$ Horticulture, COA, Azamgarh, Acharya Narendra Deva

University of Agriculture \& Technology Kumarganj Ayodhya-224229, India

${ }^{3}$ Fruit Science, Rani Lakshmi Bai Central Agricultural University, Jhansi-284003, India

*Corresponding author

\section{A B S T R A C T}

\section{Keywords}

Aonla, Vegetative growth, Fruit quality and INM

Article Info

\section{Accepted:}

26 January 2021

Available Online:

10 February 2021
Soil type, fertility and nutrient management play an important role in obtaining higher growth and yields of aonla. An investigation was conducted with aim to assess the effect integrated nutrient management on vegetative growth of cv. Francis. The study was conducted during two consecutive years. The present study revealed that Plant growth characters viz. height and spread were found to be increased significantly in all the treatments. The maximum per cent increase plant in height, trunk girth and spread were recorded with the soil application of $\mathrm{T}_{7}$ during both year which was found at par with $\mathrm{T}_{6}$. The highest TSS in aonla fruit was recorded during both the year 20018-19 and 2019-20 with the application of $\mathrm{T}_{7}$ followed by $\mathrm{T}_{6}$ and minimum TSS per cent was obtained with the use of T8. The acidity per cent was noted minimum during both the year of experimentation with the help of $\mathrm{T}_{8}$. The maximum acidity was noted with $100 \% \mathrm{FYM}$ alone treatment. Ascorbic acid (mg/ 100g pulp) content was recorded maximum in $\mathrm{T}_{7}$ during both the experimentation year which was at par with $\mathrm{T}_{6}$. Per cent reducing sugars were noticed maximum under $T_{7}$ which was at par with $T_{6}$, T5 and $T_{4}$ during both the years. The minimum non reducing sugar was obtained with the use of $\mathrm{T}_{8}$. The maximum non reducing sugar per cent was obtained with the application of $\mathrm{T}_{7}$ which was at par with $\mathrm{T}_{6}, \mathrm{~T}_{5}$ and $\mathrm{T}_{4}$ and minimum non- reducing sugar was recorded with the use of $\mathrm{T}_{8}$.

\section{Introduction}

Aonla or Indian gooseberry (Emblica officinalis Gaertn. Syn. Phyllanthus emblica) is one of the important indigenous fruits of the Indian subcontinent, known for its medicinal and therapeutic properties and considered as a wonder fruit for the healthconscious population. It has been grown and known in India for last more than 3500 years. In fact, it finds a special mention in ancient Indian text 'Ayurveda' by Sushruta, the father 
of ancient medicine during $1500 \mathrm{BC}-1300$ BC. The aonla tree is native to tropical Southeast Asia, particularly central or southern India, Pakistan, Bangladesh, Sri Lanka, Malaya, Southern China and to Mascarene Islands and it is also growing naturally in Cuba, Puerto Rico, Hawaii, Florida, Iran, Iraq, Java, West Indies, Trinidad, Singapore, southern Thailand, Pakistan, Malaya and China and Panama Canal regions.

Aonla fruit is rich in vitamin $\mathrm{C}$ and pectin. On an average, aonla fruit contains 82.2 per cent water, 0.5 per cent protein, 0.1 per cent fat, 14 per cent carbohydrates and $600 \mathrm{mg}$ vitamin $\mathrm{C} /$ $100 \mathrm{~g}$ of pulp. The fruit contains chemical substance known as leucoanthocyanins (Polyphenol), which retards the oxidation of vitamin C. It also contains calcium, phosphorus and iron. It is a fair source of vitamin $B(30 \mathrm{mg} / 100 \mathrm{~g})$ and nicotinic acid $(0.2 \mathrm{mg} / 100 \mathrm{~g})$.

The aonla fruit has calorific value of 59 per $100 \mathrm{~g}$ of fruit and due to its ant scorbutic, diuretic, laxative, alternative and antibiotic properties, it is regarded as high value having diverse medicinal, industrial and other applications. Many medicinal virtues have been attributed to aonla and have been found effective in treatment of tuberculosis of lungs, asthma, bronchitis (Kumar et al., 2016). It is also beneficial for the treatment of conjunctivitis, glaucoma, diabetes, rheumatism, diarrhoea and dysentery. It tones up the functions of all organs of the body and builds up health by destroying the heterogeneous elements and renewing the body energy. It has a revitalizing effect. It is said that the great ancient sage Mini chywan rejuvenated himself in his late $70 \mathrm{~s}$ and regained his virility by the use of aonla (Wali et al., 2015). Besides, fruits are commonly used for preparation of preserve (murabba), pickle, candy, jelly, etc. It can be dried and powdered to be used subsequently. It is also used in the preparation of inks, hair dyes, hair oils (Tripathi et al., 1988).

Soil type, fertility and nutrient management play an important role in obtaining higher growth and yields of aonla. Inadequate nutrition has very often been attributed as the cause of lower yields in aonla. Therefore, balanced nutrition is important, both for young growing plants as well as grown up fruit bearing trees. However, a bearing tree requires balanced nutrient application for maintenance of vegetative growth along with fruit production. Indiscriminate use of chemical fertilizers had adversely affected the soil fertility, water quality, yield and quality of the produce and increased level of resistance in pests (Kalloo, 2003). Due to poor physical properties of soil it becomes very hard during season and crop suffers due to deficiency of major plant nutrients (Mandal et al., 2013). Crop nutrition is one of the most essential factor, which greatly affect the yield and quality of aonla (Mustafa et al., 2013). Fruit productivity and quality can be maintained in subsequent generation by integrated nutrient management system and contribute share in input cost of production (Singh et al., 2012). Therefore, efficient use of integrated plant nutrient supply system is a prerequisite for achieving continuous advances in productivity of fruits crops in ecologically sustainable manner (Chundawat, 2001).

\section{Materials and Methods}

The experiment carried out at Main Experiment Station (MES) Horticulture A.N.D. University of Agriculture \&Technology, Kumarganj, Ayodhya (U.P.) on 28-year-old plants of aonla uniformly healthy and well-maintained square system of an orchard. 
The details of the experiment are given below-

1. Age of the tree: 28 year

2. Design: Randomized Block Design (R.B.D.)

3. Replication: 03

4. Number of treatments: 13

5. Plant Unit: 01

6. Number of plants: 39

\section{Treatment details}

$$
\begin{aligned}
& \mathrm{T}_{1}: 100 \% \operatorname{RDF}(1: 0.5: 1: \mathrm{N}: \mathrm{P}: \mathrm{K}+10 \mathrm{~kg} \\
& \text { FYM plant }{ }^{-1} \text { ) } \\
& \mathrm{T}_{2}: 75 \% \mathrm{RDF}+10 \mathrm{~kg} \text { Vermicompost } \\
& \mathrm{T}_{3}: 75 \% \mathrm{RDF}+10 \mathrm{~kg} \text { Vermicompost+ } \\
& 250 \mathrm{~g} \text { Azotobacter+ 250g PSB } \\
& \mathrm{T}_{4}: 75 \% \mathrm{RDF}+20 \mathrm{~kg} \text { Vermicompost } \\
& \mathrm{T}_{5} \quad: 75 \% \mathrm{RDF}+20 \mathrm{~kg} \text { Vermicompost }+ \\
& 250 \mathrm{~g} \text { Azotobacter }+250 \mathrm{~g} \text { PSB } \\
& \mathrm{T}_{6}: \text { : 75\% RDF }+30 \mathrm{~kg} \text { Vermicompost } \\
& \mathrm{T}_{7}: 75 \% \mathrm{RDF}+30 \mathrm{~kg} \text { Vermicompost+ } \\
& 250 \mathrm{~g} \text { Azotobacter }+250 \mathrm{~g} \text { PSB } \\
& \mathrm{T}_{8}: 50 \% \mathrm{RDF}+10 \mathrm{~kg} \text { Vermicompost } \\
& \mathrm{T}_{9}: 50 \% \mathrm{RDF}+10 \mathrm{~kg} \text { Vermicompost }+ \\
& \text { 250g Azotobacter }+250 \mathrm{~g} \text { PSB } \\
& \mathrm{T}_{10}: 50 \% \mathrm{RDF}+20 \mathrm{~kg} \text { Vermicompost } \\
& \mathrm{T}_{11}: 50 \% \mathrm{RDF}+20 \mathrm{~kg} \text { Vermicompost+ } \\
& \text { 250g Azotobacter+ 250g PSB } \\
& \mathrm{T}_{12}: 50 \% \mathrm{RDF}+30 \mathrm{~kg} \text { Vermicompost } \\
& \mathrm{T}_{13}: 50 \% \mathrm{RDF}+30 \mathrm{~kg} \text { Vermicompost+ } \\
& \text { 250g Azotobacter+ 250g PSB }
\end{aligned}
$$

\section{Total soluble solids}

It was recorded with the help of hand refractometer of 0 to $32 \%$ range at $20^{\circ} \mathrm{C}$ and mean value was expressed as per cent total soluble solids.

\section{Acidity}

The known quantity of fruit pulp (10g) was macerated and diluted in a small amount of distilled water and filtered through muscling cloth. The volume was made up to $100 \mathrm{ml}, 5$ $\mathrm{ml}$ aliquot was taken for titration. The acidity of fruit was estimated by titrating of the aliquot against $\mathrm{N} / 10 \mathrm{NaOH}$ solution using phenolphthalein as an indicator. The total titrable acidity was expressed as per cent citric acid.

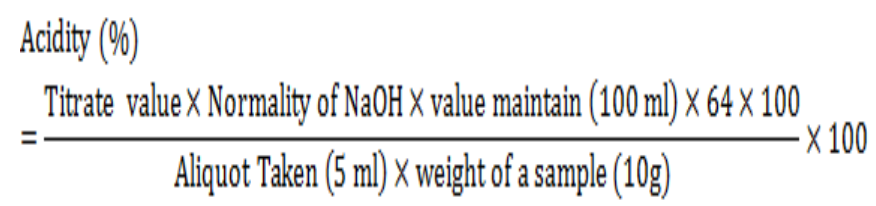

\section{Ascorbic acid}

$5 \mathrm{~g}$ fruit pulp was dissolved in 3\% metaphosphoric acid and volume was made up to $100 \mathrm{ml}$. five $\mathrm{ml}$ aliquot was titrated against standardized 2, 6-dichloro indophenol dye. The endpoint was marked as when pink colour appeared and retained for at least 15 seconds. The ascorbic acid content was expressed as mg ascorbic acid per $100 \mathrm{~g}$ of pulp (A.O.A.C., 1990).

Ascorbic acid (mg100g of pulp) $=\frac{\text { Titrate value } X \text { Dye factor X Valume made up X } 100}{\text { Aliquot of extract for estimation X Xolume of sample }}$

\section{Sugars}

\section{Reducing sugars}

The total reducing sugar was estimated by Fehling solution method as advocated by Lane and Eynon (1943). To determine the reducing sugars gram $10 \mathrm{~g}$ pulp was crushed with distilled water, filtered with muslin cloth and volume was maintained up to $100 \mathrm{ml} .5$ $\mathrm{ml}$ aliquot was taken with $5 \mathrm{ml}$ Fehling solution 'A' and 'B' in $100 \mathrm{ml}$ conical flask and titrated against 1 per cent glucose solution when boiling by using methylene blue as the indicator. The endpoint was marked by the appearance of the brick red colour. 


\section{Non-reducing sugars}

Non-reducing sugars were estimated by deducting quantity of reducing sugars from total invert sugars and multiplied by factors 0.95 . The results were expressed as per cent non reducing sugars.

\section{Total sugars}

Out of $100 \mathrm{ml}$ sample $5 \mathrm{ml}$ aliquot was taken, mixed with 3 drops of $\mathrm{HCl}$ and kept overnight. Next day 2-3 drop phenolphthalein indicator was added and neutralized with 30 per cent sodium hydroxide $(\mathrm{NaOH})$ solution. It was titrated against 1.0 per cent glucose in boiling solution using methylene blue as an indicator. The appearance of brick red colour was marked as the endpoint. The results were expressed as per cent total sugars.

Total invert sugar $=\frac{(\mathrm{B}-\mathrm{S}) \times \text { Volume made up }(100 \mathrm{ml})}{\text { Aliquot is taken }(5 \mathrm{ml}) \times \text { weight of a sample }(10 \mathrm{~g})}$

Where,

$\mathrm{B}=$ Blank reading

$\mathrm{S}=$ Sample titrate reading

\section{Results and Discussion}

Plant growth characters viz. height and spread were found to be increased significantly in all the treatments. The maximum per cent increase plant in height, trunk girth and spread were recorded with the soil application of $T_{7}$ which was at par with $T_{6}, T_{3}, T_{4}$ and $T_{5}$ and $\mathrm{T}_{1}$. It might be due to proper combination of chemical fertilizer, organic manure and bio- fertilizers. Chemical fertilizers which provide nutrient in proper amount and proportion at right time which increased vegetative growth. Farm Yard Manure and chemical fertilizers make favourable condition for growth and development of microbes of bio- fertilizers by providing the nutrients and shelter respectively. The chelating properties of vermicompost reduce nutrient losses and also improve the physical and chemical properties of soil, making suitable condition for plant growth. In addition to this bio-fertilizer also fixes the atmospheric nitrogen and solubulize the soil natural phosphorus during entire crop period and also improved the efficiency of applied phosphorus. These synergistic effects of different sources of nutrient of each other, might distinguished these treatments over rest of the treatment. Similar results are also noted by Yadav et al., (2007) and reported 50\% $\mathrm{NPK}+25 \mathrm{~g}$ sulphur + 100kg FYM + 200g each (Azotobacter + Azospirillum + PSB) gave maximum per cent increase in plant growth in aonla.

Gogaiet al. (2004) studied the effect of biofertilizer (Azotobacter + Azospirillum + PSB) in combination with the recommended dose of NPK fertilizers and half dose of recommended dose of $\mathrm{N}$ on growth and development of banana. The treatment combination of $50 \%$ recommended dose of $\mathrm{N}+\mathrm{RD}$ of $\mathrm{K}+$ biofertilizers (Azospirillum omozonere + Bacillus + megatricum) resultant in maximum plant height, girth, leaf area and leaf area index at shooting stage, functional leaves at large stage, number of leaves and reduced the duration of shooting to harvesting.

Manjunatha et al., (2002) reported, papaya plant responded better increasing plant height with the application of Glomus fasciculatum with $75 \%$ recommended dose of phosphorus also on in combination. The results are also corroborating with the findings of Sharma $e t$ al., (2003) as application of integrated nutrient management through Vermicompost and inorganic fertilizer 50:50 favoured the plant growth and yield of pomegranate crop while the combination of sheep and cattle manure improved the water holding capacity under sandy soil (Table 1-3). 
Table.1 Effect of integrated nutrient management on vegetative growth of aonla

\begin{tabular}{|c|c|c|c|c|c|}
\hline \multirow{2}{*}{\multicolumn{2}{|c|}{ Treatments }} & \multicolumn{2}{|c|}{ Plant height (\% increase) } & \multicolumn{2}{|c|}{ Plant spread (\% increase) } \\
\hline & & \multirow{2}{*}{\begin{tabular}{|l|}
2018 \\
8.01
\end{tabular}} & \multirow{2}{*}{$\begin{array}{l}2019 \\
11.53\end{array}$} & \multirow{2}{*}{\begin{tabular}{|c|}
2018 \\
14.87
\end{tabular}} & \multirow{2}{*}{$\begin{array}{c}2019 \\
15.48\end{array}$} \\
\hline $\mathbf{T}_{1}$ & $100 \% \operatorname{RDF}\left(1: 0.5: 1: \mathrm{N}: \mathrm{P}: \mathrm{K}+10 \mathrm{~kg}\right.$ FYM plant $\left.^{-1}\right)$ & & & & \\
\hline $\mathbf{T}_{2}$ & $75 \% \mathrm{RDF}+10 \mathrm{~kg}$ Vermicompost & 10.21 & 13.95 & 16.14 & 19.48 \\
\hline $\mathbf{T}_{3}$ & $75 \% \mathrm{RDF}+10 \mathrm{~kg}$ Vermicompost $+250 \mathrm{~g}$ Azotobacter $+250 \mathrm{~g}$ PSB & 12.41 & 21.88 & 21.04 & 23.73 \\
\hline $\mathbf{T}_{4}$ & $75 \% \mathrm{RDF}+20 \mathrm{~kg}$ Vermicompost & 11.01 & 19.73 & 18.44 & 21.58 \\
\hline $\mathbf{T}_{5}$ & $75 \% \mathrm{RDF}+20 \mathrm{~kg}$ Vermicompost $+250 \mathrm{~g}$ Azotobacter $+250 \mathrm{~g} \mathrm{PSB}$ & 13.81 & 25.31 & 24.74 & 24.84 \\
\hline $\mathbf{T}_{6}$ & $75 \% \mathrm{RDF}+30 \mathrm{~kg}$ Vermicompost & 11.71 & 21.23 & 20.54 & 22.34 \\
\hline $\mathbf{T}_{7}$ & $75 \% \mathrm{RDF}+30 \mathrm{~kg}$ Vermicompost $+250 \mathrm{~g}$ Azotobacter $+250 \mathrm{~g}$ PSB & 16.26 & 26.45 & 26.11 & 27.02 \\
\hline $\mathbf{T}_{8}$ & $50 \% \mathrm{RDF}+10 \mathrm{~kg}$ Vermicompost & 8.41 & 13.33 & 15.44 & 19.28 \\
\hline $\mathbf{T}_{9}$ & $50 \% \mathrm{RDF}+10 \mathrm{~kg}$ Vermicompost $+250 \mathrm{~g}$ Azotobacter $+250 \mathrm{~g}$ PSB & 12.01 & 21.53 & 20.74 & 23.08 \\
\hline $\mathbf{T}_{10}$ & $50 \% \mathrm{RDF}+20 \mathrm{~kg}$ Vermicompost & 10.51 & 14.63 & 16.94 & 19.68 \\
\hline $\mathbf{T}_{11}$ & $50 \% \mathrm{RDF}+20 \mathrm{~kg}$ Vermicompost $+250 \mathrm{~g}$ Azotobacter $+250 \mathrm{~g}$ PSB & 13.01 & 23.03 & 22.33 & 24.35 \\
\hline $\mathbf{T}_{12}$ & $50 \% \mathrm{RDF}+30 \mathrm{~kg}$ Vermicompost & 11.01 & 19.23 & 18.34 & 21.28 \\
\hline \multirow[t]{3}{*}{$\mathbf{T}_{13}$} & $50 \% \mathrm{RDF}+30 \mathrm{~kg}$ Vermicompost $+250 \mathrm{~g}$ Azotobacter $+250 \mathrm{~g}$ PSB & 13.31 & 24.73 & 22.91 & 24.38 \\
\hline & $\mathrm{SEm} \pm$ & 0.47 & 0.58 & 0.63 & 0.77 \\
\hline & $\mathrm{CD}$ & 1.37 & 1.71 & 1.86 & 2.27 \\
\hline
\end{tabular}


Table.2 Effect of INM on TSS and acidity of aonla

\begin{tabular}{|c|c|c|c|c|c|}
\hline \multirow{2}{*}{\multicolumn{2}{|c|}{ Treatments }} & \multicolumn{2}{|c|}{$\begin{array}{c}\text { Total soluble solids } \\
\text { ( }{ }^{0} \text { Brix) }\end{array}$} & \multicolumn{2}{|c|}{ Acidity (\%) } \\
\hline & & 2018 & 2019 & 2018 & 2019 \\
\hline $\mathbf{T}_{1}$ & $100 \% \operatorname{RDF}\left(1: 0.5: 1: \mathrm{N}: \mathrm{P}: \mathrm{K}+10 \mathrm{~kg}\right.$ FYM plant $\left.{ }^{-1}\right)$ & 9.47 & 9.84 & 1.770 & 1.820 \\
\hline $\mathbf{T}_{2}$ & $75 \% \mathrm{RDF}+10 \mathrm{~kg}$ Vermicompost & 9.77 & 9.87 & 1.690 & 1.740 \\
\hline $\mathbf{T}_{3}$ & $75 \% \mathrm{RDF}+10 \mathrm{~kg}$ Vermicompost $+250 \mathrm{~g}$ Azotobacter $+250 \mathrm{~g}$ PSB & 9.98 & 10.07 & 1.470 & 1.520 \\
\hline $\mathbf{T}_{4}$ & $75 \% \mathrm{RDF}+20 \mathrm{~kg}$ Vermicompost & 9.86 & 9.96 & 1.580 & 1.630 \\
\hline $\mathbf{T}_{5}$ & $75 \% \mathrm{RDF}+20 \mathrm{~kg}$ Vermicompost $+250 \mathrm{~g}$ Azotobacter $+250 \mathrm{~g}$ PSB & 11.03 & 11.150 & 1.400 & 1.440 \\
\hline $\mathbf{T}_{6}$ & $75 \% \mathrm{RDF}+30 \mathrm{~kg}$ Vermicompost & 9.90 & 10.00 & 1.550 & 1.600 \\
\hline $\mathbf{T}_{7}$ & $75 \% \mathrm{RDF}+30 \mathrm{~kg}$ Vermicompost $+250 \mathrm{~g}$ Azotobacter $+250 \mathrm{~g}$ PSB & 11.15 & 11.25 & 1.360 & 1.410 \\
\hline $\mathbf{T}_{8}$ & $50 \% \mathrm{RDF}+10 \mathrm{~kg}$ Vermicompost & 9.76 & 9.86 & 1.720 & 1.780 \\
\hline $\mathbf{T}_{9}$ & $50 \% \mathrm{RDF}+10 \mathrm{~kg}$ Vermicompost $+250 \mathrm{~g}$ Azotobacter $+250 \mathrm{~g}$ PSB & 9.93 & 10.03 & 1.500 & 1.550 \\
\hline $\mathbf{T}_{10}$ & $50 \% \mathrm{RDF}+20 \mathrm{~kg}$ Vermicompost & 9.80 & 9.90 & 1.640 & 1.700 \\
\hline $\mathbf{T}_{11}$ & $50 \% \mathrm{RDF}+20 \mathrm{~kg}$ Vermicompost $+250 \mathrm{~g}$ Azotobacter $+250 \mathrm{~g}$ PSB & 10.01 & 10.11 & 1.440 & 1.490 \\
\hline $\mathbf{T}_{12}$ & $50 \% \mathrm{RDF}+30 \mathrm{~kg}$ Vermicompost & 9.83 & 9.93 & 1.610 & 1.660 \\
\hline $\mathbf{T}_{13}$ & $50 \% \mathrm{RDF}+30 \mathrm{~kg}$ Vermicompost $+250 \mathrm{~g}$ Azotobacter $+250 \mathrm{~g}$ PSB & 10.50 & 10.60 & 1.410 & 1.460 \\
\hline & $\mathrm{SEm} \pm$ & 0.44 & 0.29 & 0.03 & 0.05 \\
\hline & $\mathrm{CD}$ & 1.28 & 0.86 & 0.10 & 0.15 \\
\hline
\end{tabular}


Table.3 Effect of INM on ascorbic acid, reducing sugar and non reducing sugar of aonla

\begin{tabular}{|c|c|c|c|c|c|c|c|}
\hline \multirow{2}{*}{\multicolumn{2}{|c|}{ Treatments }} & \multicolumn{2}{|c|}{$\begin{array}{l}\text { Ascorbic acid } \\
\text { (mg/100g pulp) }\end{array}$} & \multicolumn{2}{|c|}{ Reducing sugar (\%) } & \multicolumn{2}{|c|}{$\begin{array}{c}\text { Non Reducing sugar } \\
(\%)\end{array}$} \\
\hline & & 2018 & 2019 & 2018 & 2019 & 2018 & 2019 \\
\hline $\mathbf{T}_{1}$ & $100 \%$ RDF (1:0.5:1: N: P: K + 10kg FYM plant $\left.{ }^{-1}\right)$ & 475.2 & 479.60 & 2.60 & 2.64 & 2.51 & 2.55 \\
\hline $\mathbf{T}_{2}$ & $75 \% \mathrm{RDF}+10 \mathrm{~kg}$ Vermicompost & 491.4 & 495.9 & 2.68 & 2.73 & 2.59 & 2.63 \\
\hline $\mathbf{T}_{3}$ & $\begin{array}{l}75 \% \mathrm{RDF}+10 \mathrm{~kg} \text { Vermicompost }+250 \mathrm{~g} \text { Azotobacter }+ \\
250 \mathrm{~g} \text { PSB }\end{array}$ & 561.60 & 566.80 & 3.07 & 3.12 & 2.96 & 3.01 \\
\hline $\mathbf{T}_{4}$ & $75 \% \mathrm{RDF}+20 \mathrm{~kg}$ Vermicompost & 523.8 & 528.7 & 2.86 & 2.91 & 2.76 & 2.81 \\
\hline $\mathbf{T}_{5}$ & $\begin{array}{l}75 \% \mathrm{RDF}+20 \mathrm{~kg} \text { Vermicompost }+250 \mathrm{~g} \text { Azotobacter }+ \\
250 \mathrm{~g} \mathrm{PSB}\end{array}$ & 599.4 & 604.9 & 3.27 & 3.33 & 3.16 & 3.21 \\
\hline $\mathbf{T}_{6}$ & $75 \% \mathrm{RDF}+30 \mathrm{~kg}$ Vermicompost & 540.0 & 545.0 & 2.95 & 3.00 & 2.85 & 2.90 \\
\hline $\mathbf{T}_{7}$ & $\begin{array}{l}75 \% \mathrm{RDF}+30 \mathrm{~kg} \text { Vermicompost+ } 250 \mathrm{~g} \text { Azotobacter+ } \\
250 \mathrm{~g} \text { PSB }\end{array}$ & 615.60 & 621.30 & 3.36 & 3.42 & 3.25 & 3.30 \\
\hline $\mathbf{T}_{8}$ & $50 \% \mathrm{RDF}+10 \mathrm{~kg}$ Vermicompost & 486.0 & 490.5 & 2.66 & 2.70 & 2.56 & 2.61 \\
\hline $\mathbf{T}_{9}$ & $\begin{array}{l}50 \% \mathrm{RDF}+10 \mathrm{~kg} \text { Vermicompost }+250 \mathrm{~g} \text { Azotobacter }+ \\
250 \mathrm{~g} \mathrm{PSB}\end{array}$ & 550.8 & 555.9 & 3.01 & 3.06 & 2.90 & 2.95 \\
\hline $\mathbf{T}_{10}$ & $50 \% \mathrm{RDF}+20 \mathrm{~kg}$ Vermicompost & 502.2 & 506.8 & 2.74 & 2.79 & 2.65 & 2.69 \\
\hline $\mathbf{T}_{11}$ & $\begin{array}{l}50 \% \mathrm{RDF}+20 \mathrm{~kg} \text { Vermicompost+ } 250 \mathrm{~g} \text { Azotobacter+ } \\
250 \mathrm{~g} \mathrm{PSB}\end{array}$ & 572.4 & 577.7 & 3.13 & 3.18 & 3.02 & 3.07 \\
\hline $\mathbf{T}_{12}$ & $50 \% \mathrm{RDF}+30 \mathrm{~kg}$ Vermicompost & 513.0 & 517.8 & 2.80 & 2.85 & 2.70 & 2.75 \\
\hline $\mathbf{T}_{13}$ & $\begin{array}{l}50 \% \text { RDF+ } 30 \mathrm{~kg} \text { Vermicompost }+250 \mathrm{~g} \text { Azotobacter+ } \\
250 \mathrm{~g} \text { PSB }\end{array}$ & 588.6 & 594.0 & 3.22 & 3.27 & 3.10 & 3.16 \\
\hline & $\mathrm{SEm} \pm$ & 23.55 & 20.19 & 0.13 & 0.12 & 0.13 & 0.14 \\
\hline & $\mathrm{CD}$ & 68.73 & 58.93 & 0.38 & 0.35 & 0.37 & 0.42 \\
\hline
\end{tabular}


Int.J.Curr.Microbiol.App.Sci (2021) 10(02): 3340-3351

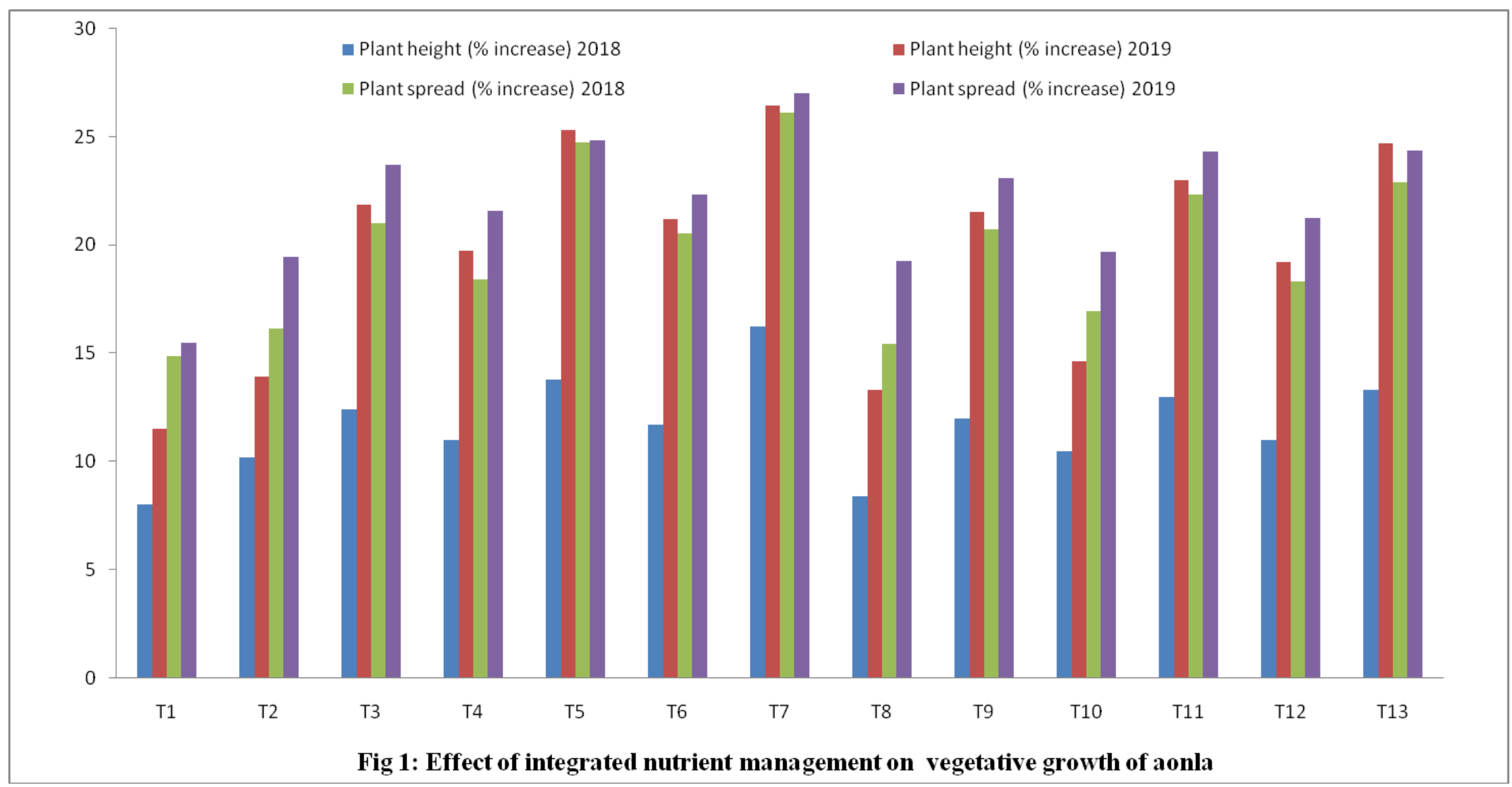


Int.J.Curr.Microbiol.App.Sci (2021) 10(02): 3340-3351

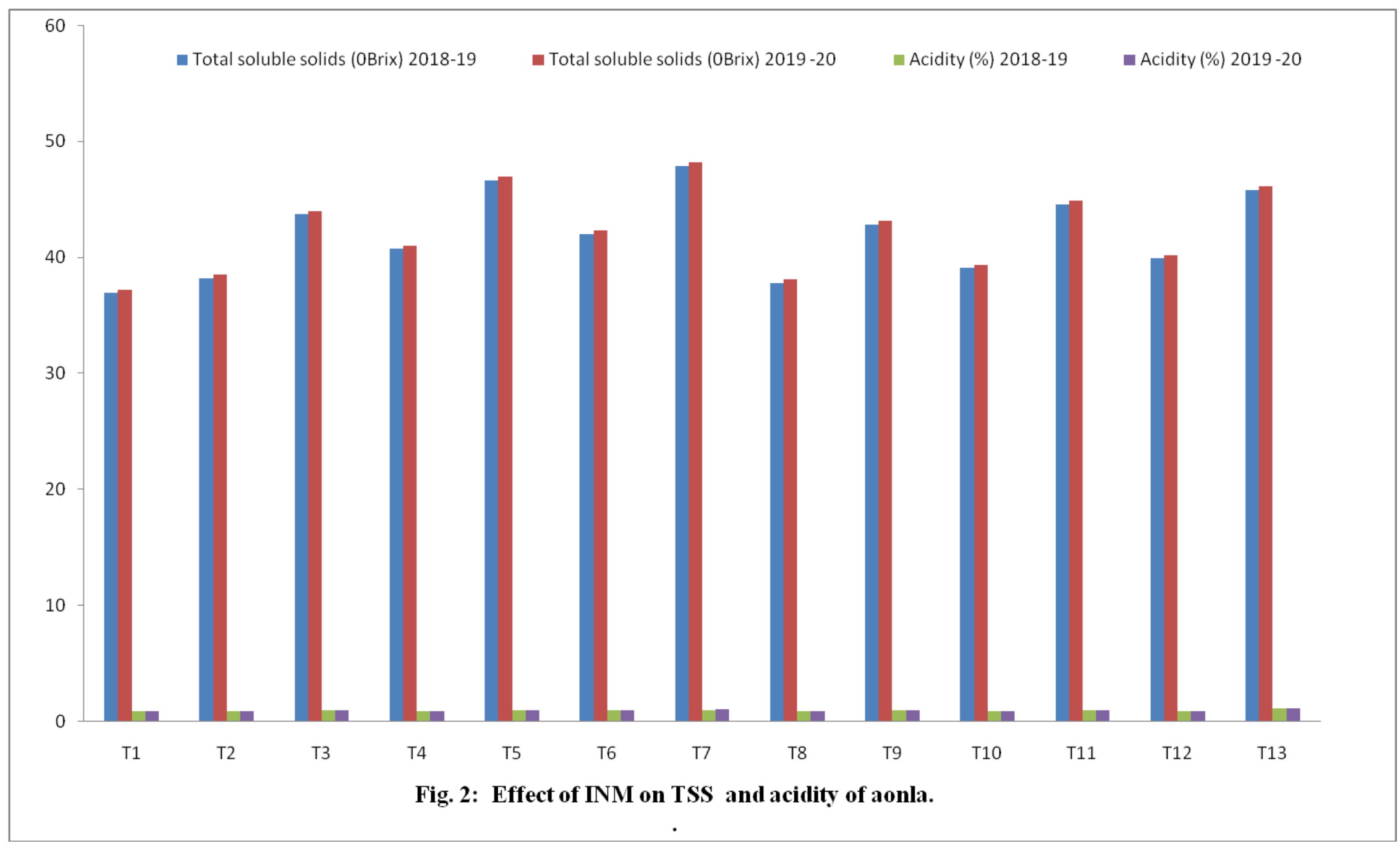


Int.J.Curr.Microbiol.App.Sci (2021) 10(02): 3340-3351

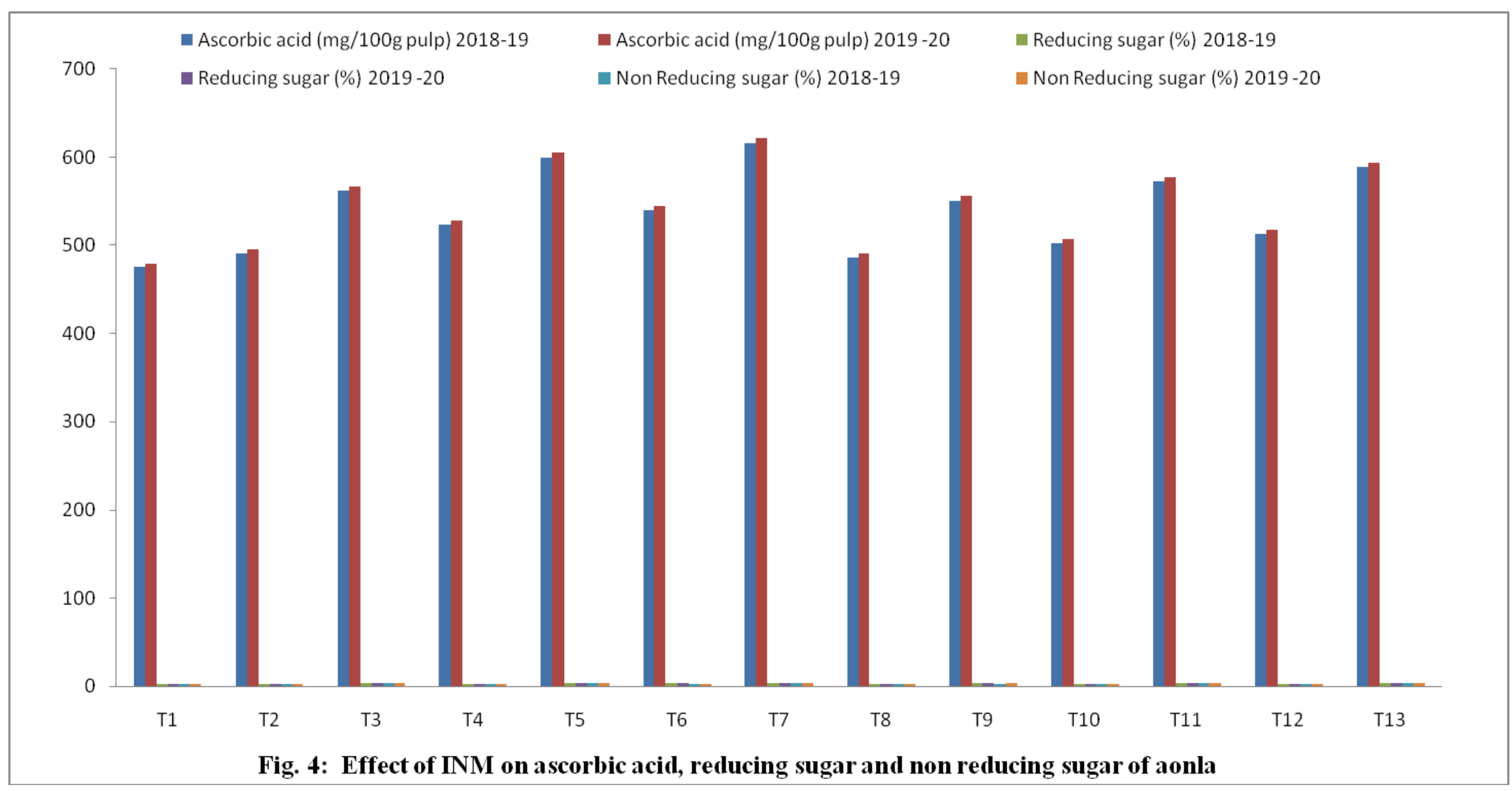


The better vegetative growth of plant observed in present investigation have also been partially supported by NareshBabu (2003) Kumar et al., (1998), Rani and Sathiamoorti (1997), Wagh and Mahajan $(1985,87)$ and Chaudhaiy et al., (1975).

Quality of fruit was influenced remarkably due to application of various treatments. The total soluble solids, non reducing, reducing and total sugars were obtained maximum with the soil application of $T_{7}$ which was at par with $\mathrm{T}_{6}$.

The minimum acidity per cent and maximum ascorbic acid content in aonla fruit were recorded with $T_{6}$. Results indicated that $T_{1}$ gave response in improving fruit quality of aonla fruit. Yadav et al., (2007) reported in guava fruit was found to be enhanced with the increased dose of FYM, biofertilizers and potassium. The results are also confirmed with the findings of Yadav et al., (2007). They conducted integrated nutrient management experiment to find out the vegetative growth, yield, quality, nutrient status in aonla leaves and improvement in soil properties and found best quality fruit with the soil application of $\mathrm{T}_{7}$. The improvement in fruit quality with the application of $T_{7}$ in present investigation was might be due to increased continuous supply of nutrients and growth promoting substances.

\section{References}

A.O.A.C. 1990. Official methods of analysis of $16^{\text {th }}$ edition. Association of Official Agricultural Chemists, Washington D.C.

Chaudhaiy, D.N.; Shyamal, N.R. and Maurya, K.R. (1975). Influence of inorganic and organic manures alone and in combination on growth, yield and chemical qualities of guava (P. guajava L.), Indian Fd. Pack., 29:24-26.
Chundawat, B.S. 2001. Integrated nutrient management in tropical and subtropical fruits. Proc. National Seminar on New Horizon in production and post management of tropical and subtropical fruits. pp. Res. 21(4): 499-503.

Kalloo, K. 2003. Research and extension activities on organic agriculture in India. Proc. Organic Farming in Horticulture for Sustainable Production, 29-30 August, CISH, .Lucknow, pp. 1.

Kumar, D. P., Hedge, M., Bhagyaraj, D.J. and Madhava Rao, A.R. (1998). Influence of biofertilizers on growth of cashew (Anacardium occidentale L.) rootstocks. Cashew, 12 (4):3-9.

Kumar, R., Pathak, S., Kumar, A., Kumar, Kumar, U. and Kumar, D.G. 2016. Studies on physico-chemical composition of aonla fruit (Embilica officinalis L.). The Bioscan, 11(4): 2375-2377.

Mandal, K. K., Rajak, A., Debnath, S. and Hasan, M. A. 2013. Integrated nutrient management in aonla cv. A-7 in the red lateritic region of West Bengal. Journal of Crop and Weed, 9(1): 121-123.

Manjunatha, V. G., Patil, C. P., Swamy, G.S.R. and Patil, P.B. 2002. Effect of different VAM fungi and phosphorus levels on yield and yield components of papaya. Karnataka Journal of Agricultural Sciences, 15(2): 336-342.

Mustafa, M.D., Pandey, S.K. Katare, S., Pandey, D. and Singh, A. 2013. Response of integrated nutrient managemnet in aonla (Emblica officinalis Gaertn.) under medium black soil. Progressive Horticulture,45(2): 385-387.

Naresh B (2003). Effect of organic inputs and potassium on growth and yield of ' $\mathrm{Co}$ 5' Papaya (Carica papaya). Indian Journal of Agricultural Sciences, 73 (4):212-214.

Rani, M.S.A. and Sathiamoorthy, S. (1997). 
Effect of organic and biofertilizers on root enzyme activity, nematode, total biomass and growth enhancement of papaya cv. Co. 6 South Indian Horticulture, 45 (5-6) :217-223.

Sharma, B.D., Dhandar, D.C. and Bhargava, R. (2003). Response of pomegranate (Punica granatum L.) to integration of nutrient sources in sandy soil of acid ecosystem. In organic farming in Horticulture for sustainable production, CISH, Lucknow, pp 33-34.

Singh, A. K., Singh, Sanjay. and Rao, V. V. A. 2012. Influence of organic and inorganic nutrient sources on soil properties and quality of aonla in hot semi-arid ecosystem. Indian Journal of Horticulture, 69 (1): 50-54.
Tripathi, V.K., Singh, M.B. and Singh, S. 1988. Studies on comparative compositional changes in different preserved products of amla (Emblica officinalis Gaertn.) var. Banarasi. Indian Food Packer, 42(4): 60-66.

Wagh, A.N. and Mahajan, P.R. (1985). Effect of nitrogen, phosphorus and potassium on quality of guava cv. Sardar, Current Research Reporter, 3: 103-104.

Wali, V.K.; Bakshi, P.; Jasrotia, A.; Bhushan, B. and Bakshi, M. 2015. Aonla. SKUAST-Jammu. pp. 30.

Yadav R; Singh, H.K. and Yadav; A.L. (2007). Effect of integrataed nutrient management on productivity and quality of aonla (Emblica officinalis Gaertn). Plant Archives 7 (2): 881- 883.

\section{How to cite this article:}

Sneha Singh, Bhanu Pratap, Vimlesh Kumar, Govind Vishwakarma, Atul Yadav, Dheeraj Yadav and Abhinav Kumar. 2021. Assess the Effect of Integrated Nutrient Management on Vegetative Growth and Quality of Aonla cv. Francis. Int.J.Curr.Microbiol.App.Sci. 10(02): 3340-3351. doi: https://doi.org/10.20546/ijcmas.2021.1002.367 